\title{
Concord Patterns with Collective Nouns in Hong Kong English. With Illustrative Material from the International Corpus of English (Hong Kong Component)
}

\author{
May Lai-Yin Wong (Hong Kong)
}

\begin{abstract}
This corpus-based study reports on both a quantitative and qualitative account of the use of collective nouns in Hong Kong English, with particular reference to subject-verb agreement/concord patterns. Singular concord was found to be the preferred pattern among thirty-five collective nouns under interrogation in the ICE-HK corpus. It is argued that the preference for singular concord serves as a signal that Hong Kong English might be less conservative than British English in converging towards the norm of using singular concord with collective nouns across the globe.
\end{abstract}

\section{$1 \quad$ Introduction}

In Tom McArthur's (2003) Oxford Guide to World English, Hong Kong English is included as a separate entry under "East Asia" heading (ibid.: 358-362), although it is non-existent in other handbooks and international English guides. ${ }^{1}$ Hong Kong English is not widely recognized and accepted to be a localised variety on a par with other Asian Englishes (such as Indian English, Malaysian English, Philippine English and Singapore English) partly because the description of Hong Kong English has been relatively under-researched, notably the grammar of this variety. ${ }^{2}$ Previously quite a number of analyses shed light on the phonetic/phonological aspects of this variety of English (e.g. Hung 2000; Peng/Ann 2004; Stibbard 2004; Setter 2006), as well as its vocabulary (e.g. Benson 1994, 2000; Carless 1995). In terms of grammar, a few studies have emerged: Budge's (1989) variable marking of plurals; Lee's (2001; 2004) usage and functions of auxiliary verbs; Gisborne's (2000) distinctive patterning of relative clauses; Wong's (2007) tag questions; to name but a few.

Local people's attitudes and ideologies also hamper the recognition of a distinct Hong Kong variety (Bolton 2000b, 2003; Bolton/Lim 2000). The rise of Hong Kong English is always linked to falling levels of English-language proficiency among local students, English language teachers and workers from all walks of life (cf., for example, Joseph 1996; Pang 2003; Kim 2006).

It is not the intention of this article to debate whether to recognise the emergence of a new variety of English or to accept a decline in English standards of local people - students and teachers alike. In this study, the term "Hong Kong English" should be taken to refer to the

\footnotetext{
${ }^{1}$ For instance, there is not any mention of "Hong Kong English" or "English in Hong Kong" or the like in Bauer's (2002) An introduction to international varieties of English; Trudgill/Hannah's (2002) International English: a guide to the varieties of Standard English; Kortmann et al.'s (2004) A handbook of varieties of English (vol. 1 \& 2); Kachru et al.'s (2006) The handbook of world Englishes.

${ }^{2} \mathrm{Cf}$. Bolton (2000a) for a guide to published research relevant to the study of Hong Kong English.
} 
English language used locally in the context of contemporary Hong Kong. Specifically, the article aims to study collective nouns in this local variety of English. Collective nouns such as committee, staff, council may take either singular or plural concord, which is in agreement with a verb where such nouns are the subject, or in agreement with a later pronoun. It has been reported by Bauer (2002: 50) that concord patterns with collective nouns are variable across varieties of English: British English favours plural concord over singular concord whereas American English takes singular concord only (Biber et al. 1999: 19). While British and American English were distinguished in this way, the variation in singular or plural concord with singular collective nouns has largely been unexplored in Asian Englishes, except for Singaporean and Philippine English (Hundt 2006). In Chinese, verbs and nouns do not inflect for number (Li/Thompson 1990) and thus it is a well-known fact that in the outercircle and expanding-circle varieties ${ }^{3}$ - quite a few do, at least variably - the third-singular ending with verbs in agreement with an unambiguously singular subject does not regularly occur (Li/Chan 1999: 80; Kachru/Nelson 2006: 170). An analysis of subject-verb agreement with singular collective nouns may have implications in this area. This study therefore focusses on singular collective nouns as subjects and examines how the following verb or pronoun agrees with them in number by looking at data from a corpus of Hong Kong English.

\section{Corpus material: ICE-HK and extraction of collective nouns}

In my work, I used the Hong Kong component of the International Corpus of English (ICEHK), which was made publicly available in March 2006 (Nelson 2006a). The ICE-HK project was initiated in the early 1990s (Bolt/Bolton 1996). The ICE-HK corpus follows the common design of other ICE corpora worldwide, containing approximately one million words and including both spoken and written data of 1.5: 1 proportion (Nelson 2006b: 736-737). Tables 1 and 2 summarise the compositions of the spoken and written ICE-HK respectively.

\begin{tabular}{lll}
\hline Dialogue & Monologue \\
\hline $\begin{array}{l}\text { S1A: PRIVATE (direct conversations and } \\
\text { telephone calls) }\end{array}$ & $\begin{array}{l}\text { S2A: UNSCRIPTED (spontaneous commen- } \\
\text { taries, unscripted speeches, demonstrations, } \\
\text { legal presentations) }\end{array}$ \\
$\begin{array}{ll}\text { S1B: PUBLIC (class lessons, broadcast } & \text { S2B: SCRIPTED (broadcast news, broadcast } \\
\text { discussions, broadcast interviews, parlia- } & \text { talks, non-broadcast talks) } \\
\text { mentary debates, legal cross-examinations, } \\
\text { business transactions) }\end{array}$ \\
\hline
\end{tabular}

Table 1: Composition of the spoken ICE-HK

\begin{tabular}{llll}
\hline Non-printed & Printed \\
\hline W1A: NON-PROFESSIONAL WRITING & W2A: ACADEMIC WRITING (Humanities, \\
(student essays and examination scripts) & $\begin{array}{l}\text { social sciences, natural sciences and } \\
\text { technology) }\end{array}$ & & \\
W1B: CORRESPONDENCE (social letters and & W2B: & NON-ACADEMIC & WRITING \\
\hline
\end{tabular}

\footnotetext{
3 In Kachru's (1985; 1992) concentric-circles model for English as a global language, the inner-circle of English is made up of countries (e.g. UK, New Zealand, etc.) where English is a native language; the outer-circle of English contains those countries (e.g. India, Nigeria, Malaysia, etc.) where English is a post-colonial second language; the expanding circle is made up of those countries (e.g. China, Indonesia, Nepal, etc.) where English is a foreign language. As Melchers/Shaw (2003: 169) remark, "Hong Kong English is somewhat closer to a foreign-language variety than the Malaysian/Singapore variety".
} 


\begin{tabular}{ll}
\hline Non-printed & Printed \\
\hline business letters) & (Humanities, social sciences, natural \\
sciences and technology) & \\
& W2C: REPORTAGE (Press news reports) \\
& W2D: INSTRUCTIONAL WRITING \\
& (administrative writing and skills \& hobbies) \\
& W2E: PERSUASIVE WRITING (press edi- \\
torials) & \\
W2F: CREATIVE WRITING (novels \& stories) \\
\hline
\end{tabular}

Table 2: Composition of the written ICE-HK

Bolton/Nelson's (2002) account has pioneered in the analysis of segments from the ICE-HK corpus for studying linguistic features of Hong Kong English. Certain linguistic features, visà-vis, the suprasegmentals of the Hong Kong accent, the noun phrase structure, phrasal verbs and coordination are highlighted as potential research areas. In its present form as a lexical corpus however, ICE-HK does not allow for interrogation of these features without the help of part-of-speech tagging and other levels of annotation such as syntactic and prosodic annotation (cf. McEnery et al. (2006: 33-43) for the state-of-the-art description of these annotation types). Yet this is not to undervalue the corpus as a long-awaited, wide-ranging resource for empirical research into Hong Kong English, particularly in the context of collective nouns which can be extracted by a purely lexical search.

In this study, I followed more or less the same procedures adopted by Hundt (2006: 212-214) for retrieving collective nouns. Like Hundt (ibid.), I chose to include most of the nouns listed in Quirk et al. (1985: 316) and excluded only those that occurred very infrequently in a onemillion-word corpus (e.g. jury and enemy). A total of thirty-five collective nouns were included:

army, association, audience, board, cast, clan, class, club, college, commission, committee, community, company, corporation, council, couple, crew, crowd, department, family, federation, gang, generation, government, group, institute, majority, ministry, minority, opposition, party, population, staff, team, university.

Only the singular form (e.g. crew, audience, etc.) of a collective noun was under investigation - disregarding the plural form (e.g. crews, audiences, etc.) - for the sake of simplicity (cf. Aremo 2005). Obviously, only verbs that allow for number marking (i. e. finite, indicative present tenses of nonmodal verbs) were considered in the present study. In other words, I counted instances followed by finite verbs and personal pronouns that can show a distinction between singular and plural concord as exemplified in examples (1) and (2), and excluded non-finite verbs either preceded by to-infinitive as in (3) or a modal auxiliary verb e.g. will, may, must, etc. as in (4-5) as well as finite auxiliary or main verbs with past reference as in (6-7).

(1) I will stay if the Army allows me to stay, you know. (S1A)

(2) Uh for the uh for the older generation they like to go to visit temples uhm everywhere. (S1A)

(3) Afghanistan also needs stability and security, and it is up to the world community to ensure these are in place. (W2E)

(4) Well the majority of local people will stay in Hong Kong [...]. (S2A)

(5) But I think the curriculum development committee must be looking into this uhm uh uhm in into this subject. (S1B) 
(6) The majority of cases, however, had not been diagnosed previously. (W2A)

(7) The committee decided measures to control pornographic videotapes and laser discs should include heavier fines. (W2C)

Instances of invariant tags (e.g. is it/isn't it) were left out. In common with what Levin (2001: 51) did for his data, I ignored unclear instances from the spoken sections of the ICE-HK corpus and included instances with relative clauses headed by which and who followed by a singular or plural verb form, as illustrated in examples (8) and (9). In addition, all instances of the nouns as part of a proper name (e.g. the British Council, the SAR government) were included in the counts.

(8) In addition, for over eighty-five percent of the secondary school population, who learn the science and humanities in English, a large of [sic] proportion of their work on these subjects is actually tackling language. (S2B)

(9) The Industry and Technology Development Council which was established earlier this year will advise the government on [...]. (S1B)

Finally, instances of mixed agreement (i.e. the combination of a singular verb and a plural pronoun) were counted as single instances of mixed concord, as illustrated in examples (10) and (11).

(10) So where's the closest crew that I can call them back to the office, okay? (S2A)

(11) When the company is ready to send the application form, then they'll send it. (S1A)

\section{Discussion}

As can be seen from Table 3, most collective nouns (27 out of 35 or almost $80 \%$ ) prefer singular concord, although a few collective nouns commonly take plural concord. Singular concord only is found in cases such as army, board, club, corporation, crowd, federation, gang, institute and ministry, where the focus is on the group as a whole rather than on the individuals making up the group. Some examples are given as follows:

(12) Accordingly, the board has agreed to amend the first schedule to the Pharmacy and Poisons Regulations to achieve tighter control. (S1B)

(13) A crowd of people was gathering at the centre of Pacific Place. (W2F)

(14) Although the Federation was established in 1901, it was not until 9 July 1900 the Commonwealth of Australia constitution Act 1900 was enacted. (W1A)

(15) The gang has also been sending its fake credit cards overseas. (S2B)

(16) I think I think the PRC officials mainly the Ministry of Finance is extremely aware of that. $(\mathrm{S} 2 \mathrm{~A})$

\begin{tabular}{llll}
\hline & Singular concord & Plural concord & Mixed concord \\
\hline army & $100.0 \%$ & $0.0 \%$ & $0.0 \%$ \\
board & $100.0 \%$ & $0.0 \%$ & $0.0 \%$ \\
club & $100.0 \%$ & $0.0 \%$ & $0.0 \%$ \\
corporation & $100.0 \%$ & $0.0 \%$ & $0.0 \%$ \\
crowd & $100.0 \%$ & $0.0 \%$ & $0.0 \%$ \\
federation & $100.0 \%$ & $0.0 \%$ & $0.0 \%$ \\
gang & $100.0 \%$ & $0.0 \%$ & $0.0 \%$ \\
\hline
\end{tabular}




\begin{tabular}{|c|c|c|c|}
\hline & Singular concord & Plural concord & Mixed concord \\
\hline institute & $100.0 \%$ & $0.0 \%$ & $0.0 \%$ \\
\hline ministry & $100.0 \%$ & $0.0 \%$ & $0.0 \%$ \\
\hline community & $95.0 \%$ & $5.0 \%$ & $0.0 \%$ \\
\hline department & $95.0 \%$ & $5.0 \%$ & $0.0 \%$ \\
\hline university & $95.0 \%$ & $5.0 \%$ & $0.0 \%$ \\
\hline government & $94.8 \%$ & $5.2 \%$ & $0.0 \%$ \\
\hline council & $91.9 \%$ & $8.1 \%$ & $0.0 \%$ \\
\hline committee & $90.9 \%$ & $9.1 \%$ & $0.0 \%$ \\
\hline association & $90.5 \%$ & $9.5 \%$ & $0.0 \%$ \\
\hline party & $86.5 \%$ & $13.5 \%$ & $0.0 \%$ \\
\hline class & $86.4 \%$ & $13.6 \%$ & $0.0 \%$ \\
\hline company & $86.2 \%$ & $12.3 \%$ & $1.5 \%$ \\
\hline family & $86.0 \%$ & $14.0 \%$ & $0.0 \%$ \\
\hline college & $83.3 \%$ & $16.7 \%$ & $0.0 \%$ \\
\hline cast & $75.0 \%$ & $25.0 \%$ & $0.0 \%$ \\
\hline crew & $75.0 \%$ & $0.0 \%$ & $25.0 \%$ \\
\hline team & $72.7 \%$ & $27.3 \%$ & $0.0 \%$ \\
\hline commission & $66.7 \%$ & $33.3 \%$ & $0.0 \%$ \\
\hline population & $66.7 \%$ & $33.3 \%$ & $0.0 \%$ \\
\hline group & $65.5 \%$ & $34.5 \%$ & $0.0 \%$ \\
\hline staff & $28.0 \%$ & $72.0 \%$ & $0.0 \%$ \\
\hline generation & $23.5 \%$ & $70.6 \%$ & $5.9 \%$ \\
\hline couple & $20.0 \%$ & $80.0 \%$ & $0.0 \%$ \\
\hline audience & $14.3 \%$ & $85.7 \%$ & $0.0 \%$ \\
\hline majority & $11.1 \%$ & $88.9 \%$ & $0.0 \%$ \\
\hline minority & $0.0 \%$ & $100.0 \%$ & $0.0 \%$ \\
\hline clan & $0.0 \%$ & $0.0 \%$ & $0.0 \%$ \\
\hline opposition & $0.0 \%$ & $0.0 \%$ & $0.0 \%$ \\
\hline
\end{tabular}

Table 3: concord patterns for individual collective nouns

Occurring over $80 \%$ of the time with singular concord are community, department, university, government, council, committee, association, party, class, company, family and college. Among these collective nouns, we find large numbers of proper nouns denoting decisionmaking official bodies and organisations, e.g. the Immigration Department, University of Hong Kong, the Chinese government, the Hong Kong Productivity Council, the SAR Preparatory Committee, the Hong Kong Amateur Swimming Association, the Liberal Party and the New Asia College. Biber et al. (1999: 247) note that these collective nouns - like proper nouns in general - do not allow for any contrast in number; in other words, they are typically associated with singular concord as an unmarked form. 
(17) The Social Welfare Department has no specific programme to help the husbands. (W2B)

(18) The Hong Kong government is therefore not subjected to the same degree of spending pressures that confront the governments of many democratic countries. (W2A)

(19) The Democratic Party is expected to lose further ground in the next Legco election. (W2B)

(20) Wah Yan College was founded by Mr Peter Tsui in 1919 in Hollywood Road with no more than a handful pupils at its inception. (W2B)

In contrast, a few collective nouns such as team, population and group take both singular and plural concord, although singular concord is still the preferred choice. Those collective nouns with very low frequency (less than 5) such as cast, crew and commission are not taken into account, despite the fact that they pattern similarly with team, population and group.

(21) Dupont sales team is best described as an elite sales team which is characterised by members' high education level. (S1B)

(22) With all their expensive gizmos, the Hong Kong Observatory team just haven't been making the right calls lately. (W2B)

(23) Our working population is also projected to grow as well so that will uh take off part of the impact and also part of the uh proposals. (S1B)

(24) Half the world's population live within five hours flying time of Hong Kong. (S2B)

Group differs from other collective nouns in combining with the prepositional phrase of + plural noun. It is termed "of-collective" in Biber et al. (2002: 61). The following plural noun names a set of people, animals and objects, etc. but the typical collocation that can be found in the ICE-HK corpus is one with "people" as the plural noun.

(25) So so we're still talking a very large group of people who rely on the society to help them. (S1B)

(26) Church is a place where a group of believers gather together to carry out the regular religious ceremonials. (W1A)

(27) A group of girls were running behind the ball. (W2F)

In the corpus, there are six collective nouns which predominantly occur with plural concord, i. e. staff, generation, couple, audience, majority and minority. These collective nouns are "in themselves strongly suggest number" (Levin 2001: 147) and thus it is hardly surprising that plural concord is the dominant choice among them. While staff takes plural concord over $70 \%$ of the time in Hong Kong English in a similar way as in British English (over $80 \%$ of the time; cf. Biber et al. 1999: 188), audience contrasts starkly in the two varieties of English. The word audience is exceptional in that plural concord is by far the more frequent option in Hong Kong English whereas singular concord is preferred in British English (ibid.).

(28) But I think it's partly because the older generation want the sense of being taking care of. (S1A)

(29) The majority of these indicators pertain either to the proportion of the population having or not having a specific quality. (W2A)

(30) Their consultancy staff come from a wide range of science and business backgrounds. (S2B)

(31) Uhm well I think the staff are nice. (S1A)

(32) Western audience are impressed by it because it wasn't one of those kungfu flicks that reduce the plot to a sideshow for the special effects. (S2B)

(33) But even for for popular theatre like that they they will eventually feel may be under pressure may be because the audience want to see they want to to do something along the line as well. (S1A) 
With respect to regional variation, previous studies have found that American English is more advanced in the use of singular concord than other varieties of world English; plural concord is used most frequently in British English (Quirk et al. 1985: 16-17; Biber et al. 1999: 188; Trudgill/Hannah 2002: 70). Depraetere (2003: 112-113) comments that American English is setting the norm for other world Englishes. In its concord pattern preferences, Hong Kong English shows convergence towards the globally dominant American model in that about $80 \%$ of collective nouns in ICE-HK take singular concord, slightly higher than the percentage for British English (cf. Figure 1). This finding is indeed surprising because Hong Kong was a former British colony and adopted the British system in every major aspect of the society e.g. education, judiciary and administration. However, there has already been some sign of American English being used by local people on an equal footing with British English, even though language policy in Hong Kong gives preference to the British form (Bilbow/Li 2001). If Hong Kong English shows divergence from the British model, this could be taken as evidence that Hong Kong English is slowly developing into a new local variety of English in its own right.

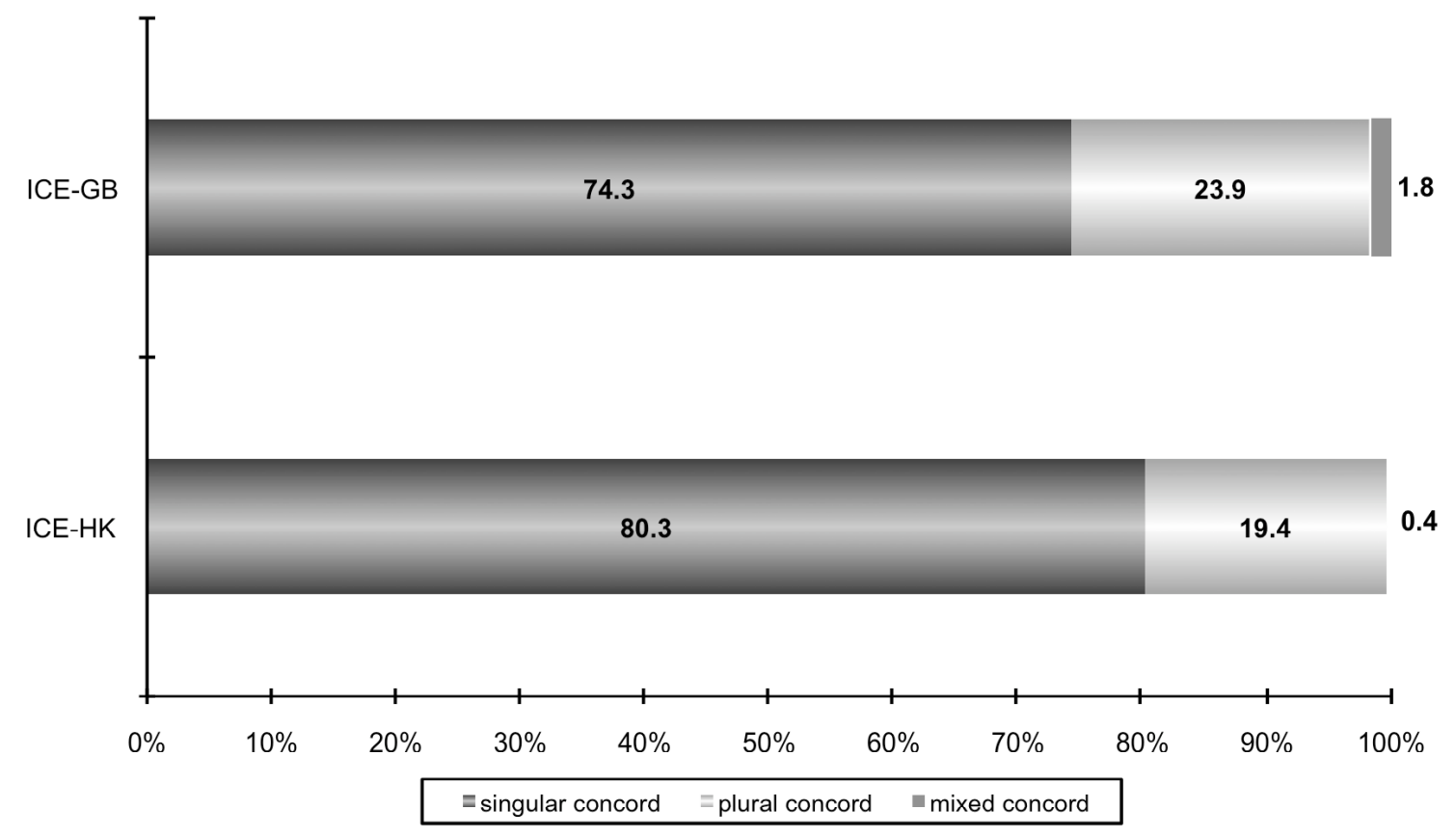

Figure 1: Concord with collective nouns in ICE-GB and ICE-HK

\section{Conclusion}

It has been shown that singular concord is the preferred pattern among thirty-five collective nouns under interrogation in the ICE-HK corpus. The preference for singular concord serves as a signal that Hong Kong English might be less conservative than British English in converging towards the norm of using singular concord with collective nouns across the globe. It is hoped that this paper can contribute to the recognition of a distinct variety of Hong Kong English by adding up to the grammatical description of this localised variety. It is also hoped that this study could possibly offer some insights into the interlanguage of Hong Kong learners of English (e.g. Newbrook 1990; Li 2000) with respect to subject-verb concord with singular collective nouns. Evidently, Hong Kong English has its own regional characteristics, which make it different from other world Englishes. 


\section{References}

Aremo, W. B. (2005): "On some uses of singular collective nouns". English Today 21/1: 5255.

Bauer, Laurie (2002): An introduction to international varieties of English. Edinburgh.

Benson, Phil (1994): "The political vocabulary of Hong Kong English". Hongkong Papers in Linguistics and Language Teaching 17/1994: 63-81.

Benson, Phil (2000): "Hong Kong words. Variation and context". World Englishes 19/3: 373380.

Biber, Douglas/Conrad, Susan/Leech, Geoffrey N. (2002): Longman student grammar of spoken and written English. Harlow.

Biber, Douglas et al. (1999): Longman grammar of spoken and written English. Harlow.

Bilbow, Grahame/Li, Lan (2001): "Following landscape with corpus evidence from Hong Kong". English Today 17/4: 27-34.

Bolt, Philip/Bolton, Kingsley (1996): "The International Corpus of English in Hong Kong. Comparing English worldwide". In: Greenbaum, Sidney (ed.): The International Corpus of English. Oxford: 197-214.

Bolton, Kingsley/Lim, Shirley (2000): "Futures for Hong Kong English". World Englishes 19/3: 429-443.

Bolton, Kingsley/Nelson, Gerald (2002): "Analysing Hong Kong English. Sample texts from the International Corpus of English". In: Bolton, Kingsley (ed.): Hong Kong English. Autonomy and creativity. Hong Kong: 241-264.

Bolton, Kingsley (2000a): "Researching Hong Kong English. Bibliographical resources". World Englishes 19/3: 445-452.

Bolton, Kingsley (2000b): "The sociolinguistics of Hong Kong and the space for Hong Kong English". World Englishes 19/3: 268-285.

Bolton, Kingsley (2003): Chinese Englishes. A sociolinguistic history. Cambridge.

Budge, Carol (1989): "Plural marking in Hong Kong English". Hongkong Papers in Linguistics and Language Teaching 12/1989: 39-47.

Carless, David (1995): "Politicised expressions in the South China Morning Post". English Today 11/2: 18-22.

Depraetere, Ilse (2003): "On verbal concord with collective nouns in British English". English Language and Linguistics 7/1: 85-127.

Gisborne, Nikolas (2000): "Relative clauses in Hong Kong English". World Englishes 19/3: 357-371.

Hundt, Marianne (2006): "'The committee has/have decided...'. On concord patterns with collective nouns in inner- and outer-circle varieties of English". Journal of English Linguistics 34/3: 206-232.

Hung, Tony (2000): "Towards a phonology of Hong Kong English". World Englishes 19/3: 337-356.

Joseph, John (1996): "English in Hong Kong. Emergence and decline". Current Issues in Language and Society 3/2: 166-179.

Kachru, Braj B./Kachru, Yamuna/Nelson Cecil L. (eds.)(2006): The handbook of world Englishes. Malden, MA/Oxford. (= Blackwell handbooks in linguistics).

Kachru, Braj B. (1985): "Standards, codification and sociolinguistic realism. The English language in the outer circle". In: Quirk, Randolph/Widdowson, Henry (eds.): English in the world. Teaching and learning the language and literatures. Cambridge: 11-36.

Kachru, Braj B. (1992): "World Englishes. Approaches, issues and resources". Language Teaching 25/1: 1-14.

Kachru, Yamuna/Nelson, Cecil (2006): World Englishes in Asian contexts. Hong Kong.

Kim, Hyun-Ju (2006): "World Englishes in language testing. A call for research". English Today 22/4: 32-39. 
Kortmann, Bernd et al. (eds.)(2004): A handbook of varieties of English. Vol. 1: Phonology, Vol. 2: Morphology and syntax. Berlin/New York.

Lee, Jackie (2001): "Functions of need in Australian English and Hong Kong English". World Englishes 20/2: 133-143.

Lee, Jackie (2004): "On the usage of have, dare, need, ought to and used to in Australian English and Hong Kong English". World Englishes 23/4: 501-513.

Levin, Magnus (2001): Agreement with collective nouns in English. Lund. (= Lund Studies in English 103).

Li, Charles/Thompson, Sandra (1990): "Chinese". In: Comrie, Bernard (ed.): The major languages of East and South-East Asia. 2nd edition. London: 83-105.

Li, David C. S./Chan, Alice Y. W. (1999): "Helping teachers correct structural and lexical English errors". Hong Kong Journal of Applied Linguistics 4/1: 79-101.

Li, David C. S. (2000): "'Hong Kong English'. New variety of English or interlanguage?" English Australia Journal 18/1: 50-59.

McArthur, Tom (2003): Oxford guide to world English. Oxford/New York.

McEnery, Tony/Xiao, Richard/Yukio, Tono (2006): Corpus-based language studies. An advanced resource book. London/New York.

Melchers, Gunnel/Shaw, Philip (2003): World Englishes. An introduction. London.

Nelson, Gerald (2006a): The ICE Hong Kong Corpus. User manual. London.

Nelson, Gerald (2006b): "World Englishes and corpora studies". In: Kachru, Braj B./ Kachru Yamuna/Nelson, Cecil (eds.): The handbook of world Englishes. Malden, MA/Oxford: 733-750.

Newbrook, Mark (1990): "Errors in focus? Native and non-native perceptions of error salience in Hong Kong student English - a case study". Hong Kong Papers in Linguistics and Language Teaching 13/1990: 71-81.

Pang, Terence (2003): "Hong Kong English. A stillborn variety?" English Today 19/2: 12-18.

Peng, Long/Ann, Jean (2004): "Obstruent voicing and devoicing in the English of Cantonese speakers from Hong Kong". World Englishes 23/4: 535-564.

Quirk, Randolph et al. (1985): A comprehensive grammar of the English language. London.

Setter, Jane (2006): "Speech rhythm in world Englishes. The case of Hong Kong". TESOL Quarterly 40/4: 763-782.

Stibbard, Richard (2004): "The spoken English of Hong Kong. A study of co-occurring segmental errors". Language, culture and curriculum 17/2: 127-142.

Trudgill, Peter/Hannah, Jean (2002): International English. A guide to the varieties of Standard English. 4th edition. London.

Tsui, Amy/Bunton, David: (2000): "The discourse and attitudes of English language teachers in Hong Kong". World Englishes 19/3: 287-303.

Wong, May L.-Y. (2007): "Tag questions in Hong Kong English. A corpus-based study". Asian Englishes 10/1: 44-61.

\section{Appendix: collective nouns in ICE-HK}

\begin{tabular}{lllll}
\hline & Singular concord & Plural concord & Mixed concord & Total \\
\hline army & 3 & 0 & 0 & 3 \\
association & 19 & 2 & 0 & 21 \\
audience & 1 & 6 & 0 & 7 \\
board & 9 & 0 & 0 & 9 \\
cast & 3 & 1 & 0 & 4
\end{tabular}




\begin{tabular}{|c|c|c|c|c|}
\hline & Singular concord & Plural concord & Mixed concord & Tota \\
\hline clan & 0 & 0 & 0 & 0 \\
\hline class & 19 & 3 & 0 & 22 \\
\hline club & 13 & 0 & 0 & 13 \\
\hline college & 5 & 1 & 0 & 6 \\
\hline commission & 4 & 2 & 0 & 6 \\
\hline committee & 30 & 3 & 0 & 33 \\
\hline community & 19 & 1 & 0 & 20 \\
\hline company & 56 & 8 & 1 & 65 \\
\hline corporation & 4 & 0 & 0 & 4 \\
\hline council & 34 & 3 & 0 & 37 \\
\hline couple & 1 & 4 & 0 & 5 \\
\hline crew & 3 & 0 & 1 & 4 \\
\hline crowd & 3 & 0 & 0 & 3 \\
\hline department & 38 & 2 & 0 & 40 \\
\hline family & 37 & 6 & 0 & 43 \\
\hline federation & 4 & 0 & 0 & 4 \\
\hline gang & 2 & 0 & 0 & 2 \\
\hline generation & 4 & 12 & 1 & 17 \\
\hline government & 202 & 11 & 0 & 213 \\
\hline group & 38 & 20 & 0 & 58 \\
\hline institute & 9 & 0 & 0 & 9 \\
\hline majority & 4 & 32 & 0 & 36 \\
\hline ministry & 4 & 0 & 0 & 4 \\
\hline minority & 0 & 5 & 0 & 5 \\
\hline opposition & 0 & 0 & 0 & 0 \\
\hline party & 45 & 7 & 0 & 52 \\
\hline population & 16 & 8 & 0 & 24 \\
\hline staff & 7 & 18 & 0 & 25 \\
\hline team & 16 & 6 & 0 & 22 \\
\hline university & 19 & 1 & 0 & 20 \\
\hline \multirow[t]{2}{*}{ Total } & 671 & 162 & 3 & 836 \\
\hline & $80.3 \%$ & $19.4 \%$ & $0.4 \%$ & \\
\hline
\end{tabular}

Note: ICE-HK = International Corpus of English - Hong Kong component. 